\title{
REGRESI LINEAR BIVARIAT SIMPEL DAN APLIKASINYA PADA DATA CUACA DI CILACAP
}

\author{
Saniyah dan Budi Pratikno \\ Program Studi Matematika Fakultas Sains dan Teknik \\ Universitas Jenderal Soedirman Purwokerto \\ Email : saniyah128@gmail.com
}

\begin{abstract}
This study discusses the simple bivariate linear regression on weather data in Cilacap district. This simple bivariate linear regression using the two response variables, rainfall $\left(Y_{1}\right)$ and humidity of an area $\left(Y_{2}\right)$, and one predictor variable, the air temperature ( $X$ ). Regression model test method is a Wilk's Lamda test, the value of Wilk's Lamda $=0.881101$ less than lambda table 0.903. The results $\left[\begin{array}{ll}\hat{Y}_{(1)} & \hat{Y}_{(2)}\end{array}\right]=[-894,130+45,892 X \quad 78,0433+0,1581 X]$ show that the model and the both parameters are significant, with mean deviation error model is $\left[\begin{array}{l}151,2132 \\ 1,206636\end{array}\right]$.
\end{abstract}

Keywords: mean deviation error, simple bivariate linear model, Wilk's Lamda test.

ABSTRAK. Penelitian ini membahas tentang regresi linear bivariat simpel pada data cuaca di Kabupaten Cilacap. Regresi linear bivariat simpel ini menggunakan dua variabel respon, curah hujan $\left(Y_{1}\right)$ dan kelembaban udara suatu wilayah $\left(Y_{2}\right)$, dan satu variabel prediktor, temperatur udara $(X)$. Metode pengujian model persamaan regresi adalah uji Wilk's Lamda, dengan nilai Wilk's Lamda $=0,881101$ bernilai lebih kecil dari lambda tabel 0,903 . Hasil uji model $\left[\begin{array}{ll}\hat{Y}_{(1)} & \hat{Y}_{(2)}\end{array}\right]=\left[\begin{array}{ll}-894,130+45,892 X & 78,0433+0,1581 X\end{array}\right]$ menunjukan bahwa parameter keduanya significant, dengan mean deviation error model tersebut adalah $\left[\begin{array}{l}151,2132 \\ 1,206636\end{array}\right]$.

Kata kunci: mean deviation error, model regresi linear bivariat simpel, uji Wilk's Lamda.

\section{PENDAHULUAN}

Dampak efek gas rumah kaca telah memberikan perubahan pada kondisi cuaca atau iklim ekstrim regional dan lokal di Indonesia. Dampak ini juga mengakibatkan tak mementunya cuaca pada suatu wilayah dan masih banyak dampak-dampak lainnya sepertinya terjadinya banjir karena hujan terus menerus, 
kekeringan karena kemarau panjang, sampai menurunnya hasil pertanian dan perkebunan. Terdapat faktor-faktor yang dapat mempengaruhi unsur iklim sehingga terjadi perbedaan iklim antara tempat yang satu dengan tempat lain (kontrol iklim). Menurut Tjasyono (1987:11) unsur-unsur iklim dan cuaca tersebut adalah temperatur udara, kelembaban udara, curah hujan, tekanan udara, angin, durasi sinar matahari, dan beberapa unsur iklim lainnya.

Analisis regresi merupakan salah satu teknik statistika yang digunakan untuk mempelajari hubungan fungsional antara variabel-variabel yang dinyatakan dalam suatu persamaan matematik. Dalam analisis regresi terdapat dua jenis variabel yaitu variabel respon atau dependen $(Y)$ dan variabel prediktor atau independen $(X)$. Model yang menggambarkan hubungan antara variabel prediktor dan variabel respon disebut dengan model regresi linear. Model regresi linear yang menggambarkan hubungan antara satu variabel respon dengan variabel prediktor yaitu model regresi linear univariat (Chatterjee dan Hadi, 2006:14). Namun pada kenyataannya variabel respon bisa lebih dari satu. Oleh karena itu model regresi linear yang dapat menggambarkan hubungan lebih dari satu variabel respon dengan variabel prediktor adalah regresi linear bivariat dan atau regresi linear multivariat. Model regresi linear bivariat merupakan model regresi linear yang menggambarkan hubungan antara dua variabel respon dengan variabel prediktor. Model regresi linear bivariat ini dapat memprediksi dan menganalisi hubungan antar dua variabel respon sekaligus yang saling berkorelasi dan perhitungan regresi linear bivariat ini biasanya menggunakan matrik.

Berdasarkan uraian diatas, penulis tertarik untuk mengetahui hubungan unsur-unsur dalam cuaca dan iklim yaitu temperatur udara, kelembaban udara, dan curah hujan dengan model regresi linear bivariat.

\section{METODE PENELITIAN}

Penelitian ini diawali dengan melakukan studi pustaka yaitu mencari, menumpulkan, dan mempelajari literatur berupa buku, jurnal dan artikel dari internet yang berhubungan dengan materi serta mencari data tentang unsur-unsur iklim dan cuaca yaitu temperatur udara $(X)$, curah hujan $\left(Y_{1}\right)$ dan kelembaban 
udara suatu wilayah $\left(Y_{2}\right)$. Data tersebut diperoleh dari Badan Meteorologi, Klimatologi, dan Geofisika Kabupaten Cilacap dari bulan Januari 2009 sampai bulan Februari 2014. Langkah berikutnya adalah sebagai berikut: (1) melakukan pengujian kebebasan antar variabel respon dengan menggunakan uji Bartlett, (2) mencari estimasi parameter model, (3) melakukan pengujian parametermodel, (4) mencari mean deviation error, dan (5) analisis model regresi linear bivariat.

\section{HASIL DAN PEMBAHASAN}

\subsection{Pengujian Kebebasan Antar Variabel Respon}

Pada variabel respon $\left(\mathbf{Y}_{1}, \mathbf{Y}_{2}, \ldots, \mathbf{Y}_{p}\right)$ dikatakan bersifat saling bebas (independent) jika matriks korelasi antar variabel membentuk matriks identitas. Menurut Morrison (2005:116-118), pengujian kebebasan antar variabel independen dapat dilakukan dengan menggunakan uji Bartlett dengan hipotesis sebagai berikut:

$H_{0}$ : Antar variabel respon bersifat independent

$H_{1}$ : Antar variabel respon bersifat dependent

Statistik uji yang digunakan adalah

$\chi^{2}=-\left\{n-1-\frac{2 p+5}{6}\right\} \ln |\mathbf{R}|$

dimana $p$ merupakan jumlah variabel respon dan $\ln |\mathbf{R}|$ merupakan logaritma natural dari determinan matriks korelasi dari masing-masing variabel respon. Metode pengambilan keputusan atau kesimpulannya yaitu $H_{0}$ ditolak jika $\chi^{2}>\chi_{\alpha, \frac{1}{2} p(p-1)}^{2}$ dengan $\frac{1}{2} p(p-1)$ merupakan derajat bebas.

Dengan menggunakan persamaan (1) pada data hujan $\left(Y_{1}\right)$ dan kelembaban udara suatu wilayah $\left(Y_{2}\right)$ diperoleh nilai $\chi^{2}=25,78254$ dimana $\chi_{0,05 ; 1}^{2}=3,84146$. Karena nilai $\chi^{2}$ untuk dua variabel respon lebih besar dari nilai $\chi_{0,05 ; 1}^{2}$ maka $H_{0}$ 
ditolak yang berarti antar variabel respon bersifat dependent sehingga analisis regresi bivariat dapat digunakan.

\subsection{Estimasi Parameter}

Model regresi linear yang dapat menggambarkan hubungan antara dua atau lebih variabel respon dengan variabel prediktor yaitu model regresi linear multivariat (Rencher, 2002:322). Model regresi linear multivariat dapat dirumuskan sebagai berikut

$$
\mathbf{Y}_{n \times p}=\mathbf{X}_{n \times(q+1)} \mathbf{B}_{(q+1) \times p}+\boldsymbol{\varepsilon}_{n \times p}
$$

dimana $\mathbf{Y}$ adalah matriks variabel respon, $\mathbf{X}$ adalah matriks variabel prediktor, B adalah matriks parameter regresi dengan $\mathbf{B}=\left(\boldsymbol{\beta}_{(1)}, \boldsymbol{\beta}_{(2)}, \ldots, \boldsymbol{\beta}_{(p)}\right)$, $\boldsymbol{\varepsilon}$ adalah error, $p$ adalah banyaknya respon, $n$ adalah banyaknya pengamatan dengan $n>q+1$, dan $q$ adalah banyaknya variabel prediktor. Pada persamaan (2), untuk respon ke- $i$ dapat ditulis sebagai berikut

$$
\mathbf{Y}_{(i)}=\mathbf{X B}_{(i)}+\boldsymbol{\varepsilon}_{(i)}
$$

dengan $E\left(\boldsymbol{\varepsilon}_{i}\right)=\mathbf{0}$ dan $\operatorname{Cov}\left(\boldsymbol{\varepsilon}_{(i)}, \boldsymbol{\varepsilon}_{(k)}\right)=\sigma_{i k} \mathbf{I}$, untuk $i, k=1,2, \ldots, p$ dan $\mathbf{I}$ adalah matriks identitas (Johnson dan Wichern, 2007:388). Regresi linear bivariat merupakan regresi linear yang menggambarkan hubungan dua variabel respon dengan satu atau lebih variabel prediktor. Model regresi linear bivariat dapat dirumuskan sebagai berikut

$$
\mathbf{Y}_{n \times 2}=\mathbf{X}_{n \times(q+1)} \mathbf{B}_{(q+1) \times 2}+\boldsymbol{\varepsilon}_{n \times 2}
$$

Untuk mengestimasi parameter B digunakan metode kuadrat terkecil (least square), sehingga estimasiparameter $\mathbf{B}$ yaitu $\hat{\mathbf{B}}=\left(\mathbf{X}^{\prime} \mathbf{X}\right)^{-1} \mathbf{X}^{\prime} \mathbf{Y}$. Selanjutnya dengan menggunakan rumus sebelumnya diperoleh estimasi parameter yaitu $\hat{\mathbf{B}}=\left[\begin{array}{cc}-894,130 & 78,0433 \\ 45,892 & 0,1581\end{array}\right] \quad$ dimana $\quad \hat{\boldsymbol{\beta}}_{(1)}=\left[\begin{array}{c}-894,130 \\ 45,892\end{array}\right] \quad$ dan $\quad \hat{\boldsymbol{\beta}}_{(2)}=\left[\begin{array}{c}78,0433 \\ 0,1581\end{array}\right]$. 
Sehingga peramalan model regresi linear bivariat sederhana adalah sebagai berikut

$$
\left[\begin{array}{ll}
\hat{Y}_{(1)} & \hat{Y}_{(2)}
\end{array}\right]=[-894,130+45,892 X \quad 78,0433+0,1581 X] .
$$

\subsection{Pengujian Signifikansi Parameter pada Model Regresi Linear Bivariat}

Setelah mendapatkan parameter untuk model regresi linear bivariat langkah selanjutnya yaitu pengujian signifikansi parameter. Pengujian ini menggunakan uji Wilk's Lamda dengan hipotesis sebagai berikut

$H_{0}: \beta_{11}=\beta_{12}=0$ atau parameter tidak signifikan terhadap model

$H_{1}$ : Paling sedikit ada satu $\beta_{q p} \neq 0$ atau paling sedikit ada satu parameter yang signifikan terhadap model

Statistik uji yang digunakan adalah

$$
\Lambda=\frac{|E|}{|E+H|}=\frac{\left|\mathbf{Y}^{\prime} \mathbf{Y}-\hat{\mathbf{B}}^{\prime} \mathbf{X}^{\prime} \mathbf{Y}\right|}{\left|\mathbf{Y}^{\prime} \mathbf{Y}-n \overline{\mathbf{y}} \overline{\mathbf{y}}^{\prime}\right|}=0,881101
$$

Melalui pengujian hipotesis diatas diketahui bahwa nilai Wilk's Lamda sebesar 0,881101 dan nilai $\Lambda_{0,05 ; 2 ; 1 ; 60}=0,903$ Karena nilai $\Lambda=0,881101<\Lambda_{0,05 ; 2 ; 1 ; 60}=0,903$ maka $H_{0}$ ditolak yang berarti bahwa parameter signifikan berpengaruh pada model regresi linear bivariat.

\subsection{Mean Deviation Error}

Mean deviation error $\left(M D_{E}\right)$ atau simpangan rata-rata error merupakan jumlah keseluruhan nilai mutlak penyimpangan nilai error terhadap nilai rata-rata error di bagi jumlah frekuensi atau pengamatan. Rumus $M D_{E}$ sebagai berikut

$$
M D_{E}=\frac{\sum_{i=1}^{n}\left|\boldsymbol{\varepsilon}_{i}-\overline{\boldsymbol{\varepsilon}}\right|}{n}, \boldsymbol{\varepsilon}_{i}=\left[\begin{array}{c}
\varepsilon_{i 1} \\
\varepsilon_{i 2}
\end{array}\right], \overline{\boldsymbol{\varepsilon}}=\left[\begin{array}{c}
\overline{\boldsymbol{\varepsilon}}_{1} \\
\overline{\boldsymbol{\varepsilon}}_{2}
\end{array}\right]
$$


dengan nilai $\overline{\boldsymbol{\varepsilon}}=\left[\begin{array}{l}-0,00697 \\ 0,000441\end{array}\right]$, dimana $\overline{\boldsymbol{\varepsilon}}_{(1)}$ merupakan rata-rata error bulanan pada model pertama sebesar $-0,00697$ dan $\overline{\boldsymbol{\varepsilon}}_{(2)}$ merupakan rata-rata error bulanan pada model kedua sebesar 0,000441. Selanjutnya dengan menggunakan rumus (3.5), diperoleh nilai $M D_{E}$ untuk regresi linear bivariatnya yaitu $M D_{E}=\left[\begin{array}{l}151,2132 \\ 1,206636\end{array}\right]$, dimana $M D_{E_{(1)}}=151,2132$ dan $M D_{E_{(2)}}=1,206636$. Nilai $M D_{E_{(1)}}$ merupakan mean deviation errorpada model pertama sebesar 151,2131. Hal ini menunjukan bahwa rata-rata error pada curah hujan bulanan berdeviasi sebesar 151,2131 mm dari rata-rata error bulanannya. Sedangkan $M D_{E_{(2)}}$ merupakan mean deviation errorpada model kedua sebesar 1,206636dan ini merupakan rata-rata error pada kelembaban udara bulanan berdeviasi 1,206636 persenterhadap rata-rata error bulanannya.

\subsection{Analisis Model}

Model peramalan regresi linear bivariat sederhana yang diperoleh adalah $\left[\begin{array}{ll}\hat{Y}_{(1)} & \hat{Y}_{(2)}\end{array}\right]=[-894,130+45,892 X \quad 78,0433+0,1581 X] \quad$ dengan $\hat{Y}_{(1)}=-894,130+45,892 X$ dimana jika tempertur udara naik sebesar satu derajat Celcius maka curah hujan akan naik sebesar 45,892 $\mathrm{mm}$ dengan nilai rata-rata error bulanannya sebesar $-0,00697 \mathrm{~mm}$ dan $M D_{E_{(1)}}=151,2132$. Kemudian untuk $\hat{Y}_{(2)}=78,0433+0,1581 X$ dimana jika tempertur udara naik sebesar satu derajat Celcius maka kelembaban udara akan naik 0,1581 persendengan nilai rata-rata error bulanannya sebesar 0,000441 persen dan $M D_{E_{(2)}}=1,206636$. 


\section{KESIMPULAN}

Pada pengujian regresi linear bivariat menggunakan dua variabel respon yaitu curah hujan $\left(Y_{1}\right)$ dan kelembaban udara suatu wilayah $\left(Y_{2}\right)$ terhadap satu variabel respon yaitu temperatur udara $(X)$ pada data cuaca dari bulan Januari 2009 sampai bulan Februari 2014 dengan menggunakan uji Wilks Lamda didapatakan kesimpulan terdapat parameter yang signifikan terhadap model. Model peramalan regresi linear bivariat sederhana yang terbentuk adalah $\left[\begin{array}{ll}\hat{Y}_{(1)} & \hat{Y}_{(2)}\end{array}\right]=[-894,130+45,892 X \quad 78,0433+0,1581 X]$ dengan $M D_{E}=\left[\begin{array}{l}151,2132 \\ 1,206636\end{array}\right]$.

Model peramalan untuk $Y_{1}$ adalah $\hat{Y}_{(1)}=-894,130+45,892 X$ yang artinya jika tempertur udara naik sebesar satu derajat Celcius maka curah hujan akan naik sebesar 45,892 mm dengan nilai rata-rata error bulanannya sebesar $-0,00697 \mathrm{~mm}$ dan $M D_{E_{(1)}}=151,2132$. dan model peramalan untuk $Y_{2}$ adalah $\hat{Y}_{(2)}=78,0433+0,1581 X$ yang artinya jika tempertur udara naik sebesar satu derajat Celcius maka kelembaban udara akan naik 0,1581 persen dengan nilai rata-rata error bulanannya sebesar 0,000441 persen dan $M D_{E_{(2)}}=1,206636$.

\section{UCAPAN TERIMAKASIH}

Ucapan terimakasih kami sampaikan kepada Ibu Dra. Agustini Tripena, Br.Sb, M.Si selaku pembimbing dua dan semua pihak yang telah membantu dalam penelitian ini.

\section{DAFTAR PUSTAKA}

Chatterjee, S. and Hadi, A.S. (2006). Regression Analysis by Example, Fourth Edition.New York: A Wiley-Interscience Publication

Johnson, R.A. and Wichern, D.W. (2007). Applied Multivariate Statistical Analysis, Sixth Edition. New Jersey: Prentice Hall 
Morrison, D.F. (2005). Multivariate Statistical Methods, Third Edition. The Wharton School University of Pennsylvania

Rencher, A.C. (2002). Methods of Multivariate Analysis, Second Edition. New York: John Wiley and Sons Inc

Tjasyono, B. (1987). Iklim dan Lingkungan. Bandung: Cendekia Jaya Utama. 